\title{
THE RATIONALITY PROHIBITION OF RIBA (USURY)
}

\author{
Sofhian \\ IAIN Sultan Amai Gorontalo \\ (fiantomare@yahoo.co.id)
}

\begin{abstract}
Usury (henceforth called as riba) in fact has long been known and have been progressing in meaning. The study of riba was not only discussed seriously by Muslims but also other religions. If flashed back to more than two thousand years ago, the study of riba has been discussed by non-Muslims, such as Hindu, Buddhist, Jewish, Greek, Roman and Christian. In Islam, debate about riba and bank interest indicated that the problem of riba very closely related to the issue of muamalah especially those that occur in Banks and Non-Bank financial. Riba evolution concept toward interest cannot be separated from the development of the financial institutions. Therefore, this journal examine and analyze the substance of the issues of interest in a rational perspective, and at the end of this journal offers loss and profit sharing system as an alternative solution to the system of interest in transaction systems of bank and non-bank.

Ketertarikan mengenai kajian riba senantiasa menjadi diskusi yang tidak mengalami kejenuhan, dan bahkan masih sangat hangat didiskusikan dalam ilmu ekonomi dalam Islam. Hal ini terlihat dari pembahasan mengenai riba yang senantiasa memberi warna dalam diskursus pemikiran umat Islam dan perdebatannya hampir tidak menemukan titik temu. Perdebatan pemikiran mengenai riba dan bunga bank menunjukkan bahwa persoalan riba sebenarnya sangat terkait erat dengan persoalan muamalah khususnya yang terjadi pada lembaga-lembaga keuangan Bank dan Non Bank. Evolusi konsep riba ke bunga tidak lepas dari perkembangan lembaga-lembaga keuangan tersebut. Oleh karena itu, jurnal ini mencermati dan menganalisis secara subtansi tentang persoalan riba dalam perspektif rasional, dan di akhir tulisan ini menawarkan sistem loss and profi sharing sebagai solusi alternatif pengganti sistem bunga dalam sistem transaksi pada lembaga keuangan bank dan non bank.
\end{abstract}

Keywords: Rationality, prohibition, Riba . 


\section{A. Introduction}

Riba term strongly associated with muamalah activities . The concept of riba is one of prohibition in the transaction within the economic system of Islam, besides implementation of zakat and the prohibition of maisir (gambling), gharar and others bathil (false) things. In muamalah, the prohibition of riba will guarantee the flow of investment into direct line, the implementation of zakat will increase aggregate demand and encourage investment flows into the property, while prohibition of maisir (gambling), gharar and others bathil (false) things will ensure investment flows into the real sector for productive purposes, which will eventually increase the aggregate offer. $^{1}$

Essentially, the prohibition of riba is an absolute command to stay far away from riba because in the Quran it has clearly unlawfulness as contained in surah $\mathrm{Al}$ - Baqarah/2: 275

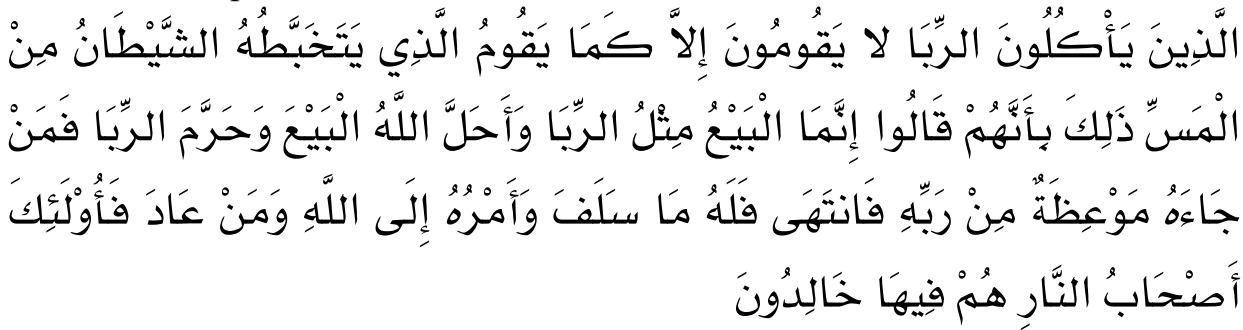

" Those who consume interest cannot stand [on the Day of Resurrection] except as one stands who is being beaten by Satan into insanity. That is because they say, "Trade is [just] like interest." But Allah has permitted trade and has forbidden interest. So whoever has received an admonition from his Lord and desists may have what is past, and his affair rests with Allah. But whoever returns to [dealing in interest or usury] - those are the companions of the Fire; they will abide eternally therein."

The elimination of riba in Islamic economy can be defined as the elimination of usury that occurs in the buying and selling and debt-receivable. In this context, the various speculative transactions which contain gharar should be prohibited. Similarly, interest that categorized as riba nasi'ah must be eliminated from the economy activity.

Riba actually very closely related to the financial and banking problems. It was not lost in our minds yet about the tragedy of the financial crisis in 1997 in which Indonesia's economy is very low, even had become a multidimensional crisis. Indonesia 's economy is dragged in the range of this

${ }^{1}$ Ascarya, Akad dan Produk Bank Syariah, (Jakarta; Raja Grafindo Persada, 2007), p. 8. 
prolonged crisis allegedly due to the management of monetary policy was not effective2. Besides that, triggered also by the foreign debt problem that had been turned into a "time bomb" those pulverize the Indonesian economy at that time. Entrepreneurs conglomerate that revered as "the largest tax payer", were like a "pillagers" of national level. Bank was not treated as agencies to help governments and communities to finance national development, but rather as a means of looting public funds and the public by conglomerates.3

As the consequence, Indonesia's economic growth reached about $7 \%$ per year suddenly dropped spectacularly to minus $15 \%$ in 1998 , then led to an inflation to $78 \%$, the number of layoffs increased, decreased purchasing power and bankruptcy partly conglomerate and business world. In a short time, from July 1997 until March 13, 1999, the government had closed no less than 55 banks, in addition to taking over 11 banks ( BTO ) and nine other banks helped to recapitalize. Meanwhile, all state-owned banks and recapitalized BPD should participate. From 240 banks that existed before the financial crisis, that was only 73 private banks can survive without government assistance. 4

The empirical facts above shows that the conventional banking system using interest, was very unstable and could not monetary flows characterized by high interest rates, so it had a negative spread . But on the contrary, Shari'ah banking system had shown itself to be a formidable system and free from negative spreads because it did not based on the system of interest.

Thus, this writing attempts to discuss the issue of riba in Islamic finance perspective. The discussion will start from the historical background reveals the emergence of riba, its concept and interest in Islamic economic, the concept of rationality Riba in Islamic finance, profit and loss sharing as rational solution to the interest, which includes the concept of money in Islam, money in the economic system of Islam, the prohibition of riba in the Islamic financial system, how to develop money that does not contain riba, and in the end discussion of this paper offers profit and loss sharing as the alternative solution to the system of interest.

\section{B. Background of Riba}

The concept of riba in fact has long been known and have been progressing in meaning. The study of riba, it was not only discussed by Muslims, but various groups outside of Islam - was looking at this issue seriously. If flashed back to more than two thousand years ago, in fact the study

${ }^{2}$ Mustafa Edwin Nasution, dkk, Pengenalan Eksklusif Ekonomi Islam, (Jakarta: Kencana, 2006), p. 261.

${ }^{3}$ Mubyanti, Membangun Sistem Ekonomi, (Yogyakarta: BPFE, 2007), p. 274

${ }^{4}$ Zainul Arifin, Memahami Bank Syariah, (Jakarta: Alvabet, 1999), p. v-vii. 
of riba has been discussed by non-Muslims, such as Hindu , Buddhist, Jewish , Greek, Roman and Christian.5

The concept of riba among Jews, known by the term " neshekh " stated as being forbidden and despised. This prohibition is widely available in their scriptures, both in the Old Testament and also in Talmud laws . Many verses in the Old Testament which prohibits the imposition of interest on loans to the poor and condemned the search of the treasure with burdening the poor with usury ${ }^{6}$ are as follows:

1. The Book of Exodus ( Exodus ) chapter 22 verse 25 states as follows:

" If you lend money to one of my people, the poor among you, do not act as debt collectors against him ; you shall not charge interest money to it" .

2. The Book of Deuteronomy ( Dt ) of Article 23, paragraph 19, states as follows:

" Thou shall not lend to thy brother, either money or food or anything that can be practiced as interest " .

3. Book Levicitus (Leviticus) chapter 25 verses 36-37 states the following:

" Do not take interest or profit from it, but you must fear your God and your brother may live with thee. Thou shall not give him thy money upon usury, nor do you give your food by asking usury".

In Ancient Greeks and Romans period, the practice of riba was become a prevailing tradition. ${ }^{7}$ Around sixth century $\mathrm{BC}$ to $1 \mathrm{AD}$, there are some types of interest. ${ }^{8}$ Meanwhile, in the Roman period, around the $\mathrm{V}$ century $\mathrm{BC}$ to the fourth $\mathrm{AD}$, there were laws that allow the population taking interest for the interest rate in accordance with "the law justified maximum level (maximum legal rate). The interest rate varies according to the changing times, but the way to take it was not justified by way of compound interest (double countable).

a. Maximum interest is justified

b. Regular loan interest in Rome

c. Flowers in the territory conquered Rome

d. Special interest Byzantium

Nonetheless, the practice of making such interest was disgraced by the Greek philosophers, including Plato ( 427-347 BC ) and Aristotle ( 384-

${ }^{5}$ Muhammad Syafi'i Antonio, Bank Syariah: dari Teori ke Praktek, (Jakarta: Gema Insani Press, 2001), p. 42.

${ }^{6}$ Ibid, p. 43.

${ }^{7}$ Islahi Abdul Azim, Economic Concepts of Ibn Taimiyah, (London: The Islamic Fondation, 1988), p. 124.

${ }^{8}$ Muhammad Syafi'i Antonio, op.cit., p. 43.

${ }^{9}$ Ibid, p. 44. 
322SM), as did the Roman philosophers, such as Cato ( 234-149 BC ), Cicero ( 106- $43 \mathrm{BCE}$ ) and Seneca ( $4 \mathrm{BC}-65 \mathrm{AD}$ ) condemned the practice of interest, which he described as inhumane acts .10

The concept of riba among Christians has different opinion, which generally can be grouped into three periods as follows :

First, the view of early Christian pastors ( I- XII century ) which forbade riba base on the Old Testament and the laws of the church. In the fourth century $\mathrm{AD}$ the Roman Catholic Church forbade riba for pastors, then expanded to the public on the fifth century AD. In the eighth century AD , under the reign of Charlemagne, the Roman Catholic Church declared the practice of riba as a crime .11

Second, the view among Christian scholars ( XII - XVI century ) which tends to allow interest, with new ground through the efforts of the law legitimizes, interest can be divided into interest and usury . From their point of view, interest is the was allowed while usury is excessive interest . Those who contributed their thought for this case were Robert of Courcon (1152-1218), William of Auxxerre (1160-1220), St. Raymond of Pennaforte (1180-1278), St. Bonaventure (1221-1274) and St. Thomas Aquinas ( 1225-1274) .12

Third, the views of the Christian reformers ( XVI century - 1836 ) as Martin Luther ( 1483-1536 ), Zwingli ( 1454-1531 ), Bucer ( 1491-1551 ) and John Calvin ( 1509-1564 ) which led to Christianity justifies the interest (interest ) . In this period, King Henry VIII decided to separate from the Roman Catholic Church, and in 1545 the interest in the UK officially allowed if was not more than $10 \%$. This policy is further strengthened by Queen Elizabeth I in 1571.13

Related to the historical background above, hence the entire of modern banking operation began to grow since the sixteenth century AD used a system of interest. The interest rate system began to grow, took root, and ingrained in the modern banking industry so it was difficult to be separated. In fact, they assume that the interest is the center of rotation of the banking system. Without interest, then the banking system becomes lifeless and eventually the economy will be paralyzed.14

${ }^{10}$ Islahi Abdul Azim, op.cit., p. 124.

11 Iqbal Zamir dan Mirakhor Abbas, An Introduction to Islamic Finance, (Wiley: John Wiley and Sons (Asia) Pte, 2007), p. 71.

${ }^{12}$ Muhammad Syafi'i Antonio, op.cit. p. 47.

13 Adiwarman Karim, Ekonomi Islam, Suatu Kajian Kontemporer, (Jakarta: Gema Insani Press, 2001), p. 72.

${ }^{14}$ Muhammad Abdul Mannan, Islamic Economic, Theory and Practice, Translator, Nastangin, (Yogyakarta: Dana Bhakti Wakaf, 1997), p. 165. 
Besides that, riba was strictly prohibited in Islam. Prohibition of riba in the Qur'an not revealed at once, but gradually, in line with the readiness of the community at that time, such as the prohibition of alcoholic drink. The prohibition of riba stages in the Qur'an can be explained as follows :

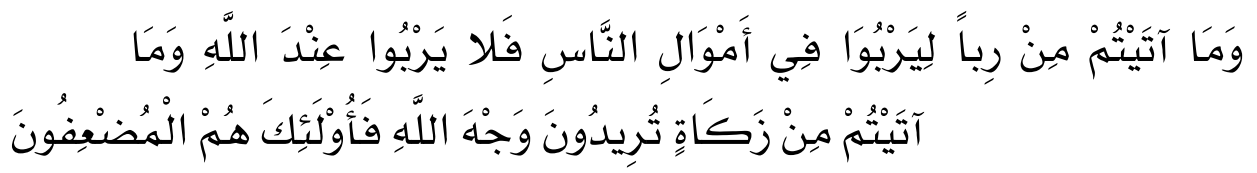

The meaning: And [remember:] whatever you may give out in usury so that it might increase through [other] people's possessions will bring [you] no increase in the sight of God-whereas all that you give out in charity, seeking God's countenance, [will be blessed by Him: for it is they, they [who thus seek His countenance] that shall have their recompense multiplied!

The second stage, in the beginning Medina period, riba was loudly condemned, in line with the prohibition on the books earlier. Riba equalized with those who take other's wealth and threatened both sides with a painful chastisement from Allah (Qur'an, An- Nisa': 160-161 ). ${ }^{16}$

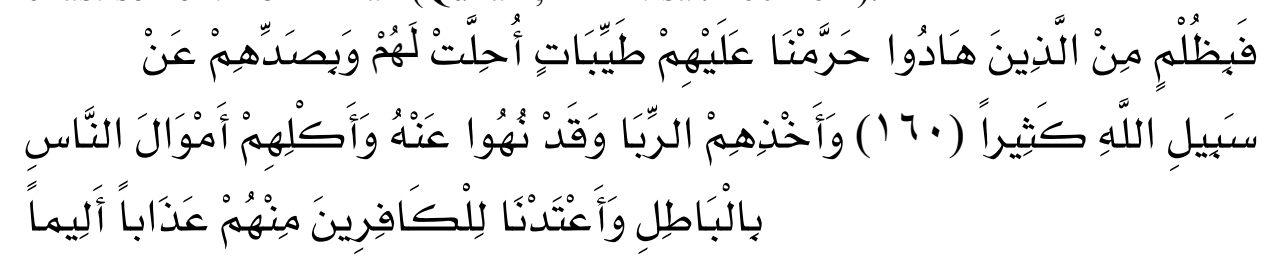

For wrongdoing on the part of the Jews, We made unlawful for them [certain] good foods which had been lawful to them, and for their averting from the way of Allah many [people],160. And [for] their taking of usury while they had been forbidden from it, and their consuming of the people's wealth unjustly. And we have prepared for the disbelievers among them a painful punishment.161

The third phase, the prohibition of riba to be associated in an additional multiplier ( QS . Ali Imron : 130 ). This verse was revealed after Uhud war 3 Hijriyah. The term of double should not be understood as a requirement then the definition was forbidden not only for doubled one but also for the little, the prohibition of riba was generally accepted happened.$^{17}$

\footnotetext{
${ }^{15}$ Religion Department, Quran and its translation.

${ }^{16}$ Ibid.

${ }^{17}$ Bank Syariah: dari Teori dan Praktek, op.cit., p. 49.
} 


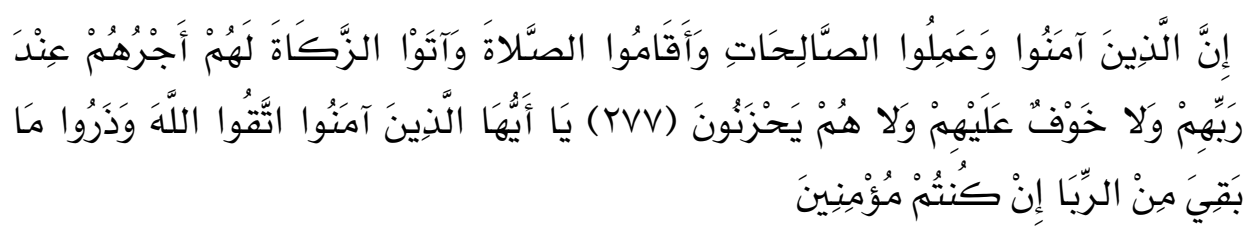

O you who have believed, fear Allah and give up what remains [due to you] of interest, if you should be believers.278. And if you do not, then be informed of a war [against you] from Allah and His Messenger. But if you repent, you may have your principal - [thus] you do no wrong, nor are you wronged. 279

\section{The concept of Riba and interest in Islamic Economics \\ 1. Definition and Types of Riba}

Etymologically, the word of " ar - riba " means 'zada wa nama', which means to add and grow. ${ }^{18}$ In the Qur'an, the word " ar-riba " and its various forms of derivatives called for twenty times ; eight of them form the word riba itself . This word is used in the Qur'an with an assortment of meanings, such as growth, added, fertilize, expands, and becomes large and numerous. Although different, but in general it means to grow, both qualitatively and quantitatively.19

Whereas the terminology, riba is generally defined as a favored profit (treasure) of one party against the other party in the transaction of sale or exchange of similar goods without reward against these advantages.20 In other terms , riba is understood as payment of a debt that must be repaid by the debtor is greater than the amount of the loan in exchange for a grace period that has elapsed time.21 By ignoring the differences opinion, generally fuqaha ' agreed that there are two kinds of riba, the riba fadl (as the first definition ) and riba nasi'ah (as the definition of a second) .

However, Abu Zahra and Yunus Rafiq al - Misri made division of riba that somewhat different from other scholars. According to both, riba was differentiate to the debt - receivable called riba nasi'ah happened to purchase that called as riba nasa ' and riba fadl . Al-Misri emphasizes the importance of

\footnotetext{
${ }^{18}$ Abadi Al-Fairuz, Al-Qamus al-Muhit, (Beirut: Dar al-Fikr, 1998), p. 332.

${ }^{19}$ Saeed Abdullah, Islamic Banking and Interest, A Study of Prohibition of Riba and its Contemporary Interprestetion, (Leiden: E.J. Brill, 1996), p. 20.

${ }^{20}$ Abdurrahman al-Jaziri, Kitab al-Fiqh 'ala Mazahib al-Arba'ah, (Beirut: Dar al-Fikr, 1972), p. 221.

${ }^{21}$ Muslim Muslihun, Fiqh Ekonomi, (Mataram, LKIM, 2005), p. 128.
} 
the distinction between riba nasi'ah and riba nasa' in order to avoid mistakes in identifying various forms of riba.

Tabel 1. Riba Typology according to Abu Zahrah abd Yunus al-Mishri

\begin{tabular}{|c|c|c|c|c|}
\hline \multirow{4}{*}{ Riba } & Transaction & Type & Elements & Gloss \\
\hline & debt - receivable & Riba Nasi'ah & $\begin{array}{l}\text { Postponement } \\
\text { addition }\end{array}$ & $\begin{array}{l}\text { Agree for the } \\
\text { unlawfulness if it } \\
\text { is dzulm and }\end{array}$ \\
\hline & \multirow[t]{2}{*}{ Purchase } & Riba Nasa' & Postponement & \multirow[t]{2}{*}{ Still under ikhtilaf } \\
\hline & & Riba Fadl & addition & \\
\hline
\end{tabular}

Source: Muslim, 2005: 132

Riba nasi'ah as what by Arab Jahiliyyah with the main characteristic manifold and exploitative agreed the unlawfulness by Muslim scholars. The current debateable is riba nasi'ah which not multiply and in a certain extent seemed not exploitative, as the much discussed related to bank interest. While riba fadl still debated among Muslim scholars. Hassan is one of the scholars who disagree with the unlawfulness under some reasons.

Expert of tafsir who allowed riba fadl were at-Tabari (died in $310 \mathrm{H} 0$. While those from Rasulullah's friends and tabi'in are Ibn Abbas (died in68 H0, Ibn Umar (died in 73 H), Zaid ibn Arqam (died in $66 \mathrm{H}$ ), Usamah bin Zaid (died in $54 \mathrm{AH}$ ), Urwah bin Zubair (died in $94 \mathrm{H}$ ), Ikrimah (d. $105 \mathrm{H}$ ), ad-Dahhak (died in $105 \mathrm{H}$ ), and Sa'id Ibn Musayyab ( died in 94 H0. Their reason was based on hadith "Look, riba was only on riba nasi'ah". According to these scholars (Ridho, $1374 \mathrm{H}$; 113-114), riba fadl is the surplus of transaction prices from similar goods not because of delays or immediate payment. The forbidden riba according to them was riba which contains added because there was a delay time (nasi'ah).

Table 2. Illat of Riba Laws

\begin{tabular}{|c|l|l|}
\hline Type of Riba & \multicolumn{1}{|c|}{ Illat Laws } & $\begin{array}{l}\text { Transaction way and } \\
\text { kind of goods }\end{array}$ \\
\hline Riba nasi'ah & Modernist: Dzulm (despotic) & Have a loan \\
\cline { 2 - 3 } & Neo-Revivalism: Ziyadah (addition) & Have a loan \\
\hline \multirow{3}{*}{} & $\begin{array}{l}\text { Abu Hanifah: same weight (ittihad al-wazn) } \\
\text { Imam Malik, Syafi'i dan Ahmad: same sort } \\
\text { in price }\end{array}$ & $\begin{array}{l}\text { Exchange } \\
\text { gold and } \\
\text { Silver }\end{array}$ \\
\hline
\end{tabular}




\begin{tabular}{|l|l|l|}
\hline Riba fadl & $\begin{array}{l}\text { Abu Hanifah: same size (ittihad al-kail) } \\
\text { Imam Malik: same sort (ittihad al-jins) and } \\
\text { including food } \\
\text { Ahmad: food under condition can be measured }\end{array}$ & $\begin{array}{l}\text { Exchange (buy) oat, } \\
\text { date and salt }\end{array}$ \\
\hline
\end{tabular}

Source: Muslim, 2005: 135.

The above differences are mainly due to varying interpretations of riba. Despite riba in al - Quran and al - Hadith explicitly judged illegitimate, but the separator unclearly defined, so it appeared diversity of interpretations. Furthermore, this issue also has implications for understanding the Muslim scholars after Rasulullah's friend generation. In fact, until now this issue is still being debated endlessly.

\section{Definition of interest}

Etymologically, the interest in The American Heritage Dictionary of the English Language is defined as the interest is a charge for a financial loan, usually a percentage of the amount loaned ${ }^{22}$ Similar definitions can be found in the Oxford English Dictionary is defined as money paid for the use of money lent ( the principal ) or for forbearance of a debt, According to a fixed ratio ( rate per cent ). While in the Legal Encyclopedia for Home and Business is defined as compensation for use of money the which is due .23

While riba is often translated in English as " usury " which means the act of lending money at Exorbitant or illegal rate of interest ${ }^{24}$ Other definitions in the Oxford English Dictionary is defined as the fact or practice of lending money at interest ; especially in later use, the practice of charging, taking or contracting to receive, excessive or illegal rate of interest for money for the loan. In the Legal Encyclopedia for Home and Business is defined as an excess over the legal rate charged the borrower for the use of money.$^{25}$

In the economic history of Europe distinguished between " usury " and " interest" . Usury is defined as the activities of lending money "where more is asked than is given" . The word "usury" is derived from the Latin "usura" which

22 Wirdyaningsih et.al, Bank dan Asuransi Islam di Indonesia, (Jakarta, Kencana, 2005), p. 21.

${ }^{23}$ Tim Pengembangan Perbankan Syariah Institut Bankir Indonesia, Bank Syariah:Konsep, Produk dan Implementasi Operasional, (Jakarta: Djambatan, 2001), p. 36.

${ }^{24}$ Wirdyaningsih, et.al, op.cit., p. 25.

${ }^{25}$ Tim Pengembangan Perbankan Syariah Institut Bankir Indonesia, op.cit., p. 
means "use " means using something . Thus, usury is the price that must be paid for using the money .

While the word " interest" is derived from the Latin "intereo" which means to lose "to be lost ". Others say that the interest is derived from the Latin " interesee" which means it comes in the middle ( to come in between ) that is compensation for losses that arise in the middle of a transaction if the borrower does not return the appropriate time ( compensation or penalty for delayed repayment of a loan ). In further developments, "interest" is not only defined as the compensation due to delay in payment of debts, but interpreted also as compensation for lost opportunity ( opportunity loss ).26

From this definition, it is clear that "interest" and "usury" as we know it today is essentially the same . Both means extra money, usually in percentage. The term "usury" arose because there was not consolidation of the financial markets at that time that the authorities have to set an interest rate that is considered "reasonable". However, after the consolidation of institutions and financial markets, the two terms were being lost because there is only one interest rate on the market in accordance with the law of supply and demand.

\section{Criticism of the Theories of Interest}

In a capitalist economic system, interest is a very important element. In fact it can be said that the power of the capitalist system of economy is interest. However it turns out, various theories are unable to explain the interest for certain whether the necessary interest in an economy or whether interest role to encourage real investment and not pushed to speculate. It is necessary for indepth analysis of the theories of interest.

In general, the development of the theory of interest can be grouped into 2 (two), the Pure Theory of Interest and Monetary Theory of Interest. The economists who support the first theory group were Adam Smith and David Ricardo, they were as adherents Classical Theory of Interest, N.W senior as Abstinence Theory of Interest, Marshall as the pioneer of Productivity Theory of Interest and Bohm Bawerk, a pioneer of Austrian Theory of Interest. Meanwhile, supporter of the theory group was A. Lerner as a pioneer of The Loanable Funds Theory of Interest and Keynesian Theory of Interest cash balance. ${ }^{27}$

In the repertoire of classical economics, the famous characters were Adam Smith and David Ricardo. Adherents of the classical theory viewed that the interest rate as compensation paid to the lender by the borrower as a service on gains from lending money. Therefore, the interest is remuneration on savings

${ }^{26}$ Rivai Veithzal, op.cit., h. 762.

${ }^{27}$ Tim Pengembangan Perbankan Syariah Institut Bankir Indonesia, op.cit., p.

$41-42$ 
expectations. Since people will not save without any hope of remuneration of savings, so this theory holds that economic interest without interest are unlikely to work. 28

Besides that, Adam Smith saw the problem as an issue of interest rates and stressed the importance of interst with 2 ( two ) foundations, namely ( 1 ) to raise sufficient capital supply ; and ( 2 ) because of the importance of the advantage of enabling the sustainability of capital .29

However it turns out, this theory has several weaknesses, which are not all savers intend to lend their money, so without interest people are also willing to save, and when the bank lent money at all illogical to say as a sacrifice .30

Meanwhile, the theory of abstinence that founded by Senior view that interest is the price paid as an act of abstinence. According to him, this is an act of abstinence for not taking action or produce activities so that if someone borrows money to someone else, then he must pay the rent on the money borrowed.31 This theory has been criticized on the grounds that the pain of sacrifice " hold lust " is different according to the level of income savers. Or can be savers do not choose to lend his money in order to remain liquid savings. Thus there is no reason for him to earn interest.32

Marshall's view as a pioneer of interest productivity theory was different from his predecessor. This theory treated productivity as a wealth that obtained in capital and the capital productivity is influenced by interest rates. Interest rate itself is determined by the interaction of supply and demand curves savings. If supply is greater than demand savings, then interest rates will go down and the investment will increase and vice versa. 33

The criticism to Smith, Ricardo and Senior can also be used to demonstrate the weakness of Marshall's theory. It is realized that ensure a balance between savings and investment is the level of income, not interest rates. The change in interest rates has small effect on savings. The increase of savings is not always followed by an increase on investment or it can be said that the high investment is not affected by low interest rates. This case can be proved even in depression condition, despite there is a decline in interest rates, but the investment does not increase. Therefore, the argument that said that

${ }^{28}$ Muhammad, Teknik Perhitungan Bagi Hasil dan Profit Margin pada Bank Syari'ah, (Yogyakarta: UII Press, 2001), p. 13.

${ }^{29}$ Afzalur Rahman, Economics Doctrines of Islam, Terjemahan Soeroyo dan Nastangin, (Jakarta: Dana Bhakti Wakaf, 2002), p. 17.

${ }^{30}$ Muhammad, op.cit., p. 15

${ }^{31}$ Muhammad Syafi'i Antonio, op.cit., p. 69.

${ }^{32}$ Tim Pengembangan Perbankan Syariah Institut Bankir Indonesia, op.cit., p. 42.

\footnotetext{
${ }^{33}$ Muhammad, op.cit., p. 13.
} 
interest rate is determined by the capital productivity is the spinning reason because the capital productivity itself is determined by interest rates. ${ }^{34}$

In another hand, Bohm Bawerk has developed a theory of interest that is similar to the Senior's theory. The Austrian pioneer theory of interest or time preference theory argues that the marginal productivity of goods is now higher than the marginal productivity of goods for the future. This theory is generalized on the basis of subjective psychological view that makes misguided understanding to the theory of interest. First, most people save without consideration that the savings in the future will be more than the current time, but rather for specific purposes, such as school, marriage, retirement, and so on. Secondly , the middle to upper level of society fertilizing their wealth for prestige and social standing, it's not because the marginal productivity of goods is now higher than goods for the future .35

The description above indicates that no single pure theory of interest that was able to explain and prove that the necessary interest in an economic activity. Some people then turned to the theory of monetary interest to try to explain how to determine the interest rate even though they do not have a solid foundation on the definition of the interest itself.

Whereas the view of Monetary Interest, one of them is Lerner who initiated the loanable funds theory. This theory goes from the concept of interest arising from savings and investments. This theory holds that the interest is determined by the interaction of supply and demand for loanable funds. While the theory of interest Keynes argued that the interest rate is determined by demand and supply of money. Therefore, Keynesians believe that savings and investment are always equal in value (balance). The first stream did not agree with this argument. From their point of view, assuming the planned savings will always be equal to the planned investments is unfounded. According to them, the interest rate is determined by the credit price and therefore regulated by the interaction of supply and demand for capital ${ }^{36}$ This theory is considered ambiguous because the analysis mix between the notion of inventory (stock) with flow.

The thought of monetary interest theory recently is performed by Keynes. He considers that the interest is not a price or remuneration on savings, but is the payment for a loan. In general, monetary interest theory considers that interest payments as opportunist actions to gain advantage and to loan. Therefore, Keynes called it as speculation motive. This motif is defined as an attempt to guarantee profit in the future. In this theory, speculation activities undertaken economic actors will affect interest rates and turns, and finally will

\footnotetext{
${ }^{34}$ Tim Pengembangan Perbankan Syariah Institut Bankir Indonesia, loc.cit.

${ }^{35}$ Ibid, p. 43.

${ }^{36}$ Muhammad, op.cit., p. 14.
} 
affect investment in production and employment levels.37 Meanwhile, Islam forbids all forms of speculation because the activity can be categorized as maysir (gambling).

When this is observed, some interest theories, the theory of pure interest and monetary interest have a number of disadvantages. Both groups of these theories are unable to explain with certainty whether the interest is needed in an economy or whether interest has a role to encourage real investment and not a speculation. Therefore, the claim emerge with regard to the interest theory until an alternative solution appear with production sharing theory in shari'a banking.

\section{Overview of Muslim Scholars (Ulama) About Bank Interest.}

Muslim scholars instruction (fatwa) about the prohibition of bank interest, had been established in an Islamic research meeting, which was attended by 150 Muslim scholars in the second conference in May 1965 in Cairo, Egypt. After that various international forums and national scholars issued a fatwa prohibiting the bank interest.

The decision of the international Islamic institutions, as follows $:^{38}$

1. The Council of Islamic Studies of al-Azhar, Cairo, the al-Azhar DSI conference in the month of Muharram 1385 H / M in May 1965, which decided that "interest in any form of a loan is forbidden riba"

2. Decision II Conference of Islamic Bank, Kuwait, 1403 H / 1983.

3. Majma 'al-Fiqh al-Islami, the Islamic Conference Organization, in Decision No. 10 Assembly Majma 'Islamic Fiqh, at the 2nd Conference of OIC in Jeddah, Saudi Arabia on 10-16 Rabi' ats-Thani 1406 H / December 22 to 28, 1985, which decided that "all additional and interest on a loan that matures and customers can not afford it, as well as additional (or interest) on loans from the beginning of the agreement is two pictures of riba that is forbidden by the Shari'a.

4. Rabita al-'Alam al-Islami, in decision No. 6, in $9^{\text {th }}$ session held in Mecca on 12-19 Rajab $1406 \mathrm{H}$, which decided that "the prevailing bank interest in conventional banking is forbidden riba".

5. Answer al-Azhar Fatwa Committee on February 28, 1988.

While the decision of Islamic institutions in Indonesia, as follows: ${ }^{39}$

1. Muhammadiyah in the Legal Affairs Committee in 1968 in Sidoarjo decided that "the bank interest of government's is mutasyabihat".

\footnotetext{
${ }^{37}$ Ibid, p. 14-15.

${ }^{38}$ Ascarya, op.cit., p. 15,

${ }^{39}$ Ibid, p. 16.
} 
2. Nahdlatul Ulama in Bahsul Masa'il Standing Committee, National Conference Bandar Lampung in 1992 issued a fatwa on bank interest to accommodate three decisions, namely the bank interest is haram, halal and doubtful (syubhat).

3. The Indonesian Ulama Council in the workshop in Cisarua 1991 decided that 1) the bank interest is riba; 2) bank interest is not same as riba; and 3) the bank interest is classified as doubtful (syubhat).

4. Lajnah Ulama Fatwa Committee in Indonesia, the Indonesian Ulama Council, in MUI Silaknas on December 16, 2003 decided that " the bank interest is riba".

5. PP Muhammadiyah, Muhammadiyah fatwa Legal Affairs Committee No. 8 in June 2006 it was announced at the National Workshop Bussiness Gathering and Economic Council Muhammadiyah on 19-21 August 2006 decided that the "bank interest is haram (unlawful)".

\section{Controversy Regarding Riba and Bank Interest}

The polemic surrounding the bank interest cannot be separated from the issue of the Islamic legal basis which called the mu'amalat where the settings is done by nash in general, and it is not described in detail, in contrast to the issue of worship and aqaid. Besides, the core problem lies in the difference in determining the 'illat around riba. Some Muslim scholars use "ziyadah" (extra) and some other who use "dzulm" (disadvantage).

At least, there are two views of a group of Muslim scholars who are very concerned looking at the status of the bank interest, namely the neorevivalism and modernist. Neo-revivalism is a movement that wants to elevate the relevance of Islam in public life today, as well as to show the strength of Islam to the Western. Neo-revivalism considered as movements tend textual because they tend to see the issue of riba (interest) from its literal side, without seeing what is practiced in the pre-Islamic period (Saeed, 1996: 49). This movement emerged in the first half of the 20th century which is a continuation of the Islamic revival movement that emerged 19th century and beginning of the 20 th century. The emergence of this movement was a reaction of secularization that occurred in Islam. They believed that Western culture as a cause of moral decadence and materialistic lifestyle. Therefore, Muslims should not altogether reject Islam and accept the values, ideas and systems of Western civilization. They believed Islam as a religion that has a brilliant civilization. 40

This movement focuses on several important issues of Muslims , especially westernization in Muslim and as an attempt to fortify themselves by placing Islam as a way of life and refuse to interpret the nash (texts). The characteristics of this group are as follows : ( 1 ) al - Quran and as- Sunnah

\footnotetext{
${ }^{40}$ Saed Abdullah, op.cit., p. 7.
} 
kaffah set way of life with all the sanctity and purity without interference from the new interpretation by considering the time and circumstances ; $(2)$ the functions performed ijtihad only to the issues not explicitly mentioned in nash ; and ( 3 ) none of the legal nash, both the Qur'an and Sunnah that need to be reinterpreted and modified. 41

The views of neo - revivalism, like Maududi and Sayyid Qutb about bank interest also cannot be separated from these characteristics. About riba, they put more emphasis on formal legal aspects of the prohibition of riba , which views all forms of interest are forbidden. Although they discuss further about the issue of injustice in riba, in general they do not say that the injustice as the reason of the prohibition. 42An expert in Islamic economics also emphasized "riba has the same meaning and import as interest" 43 . The underlying reasons, according to Muslim are: 44 (1) The statement set out in the Qur'an must be taken literal meaning, regardless of what is practiced in pre - Islamic ; (2) The Qur'an has stated that the only principal is taken, then there is no choice but to interpret riba according to the statement.

The views of the Neo - Revivalists about riba as interest is based on a literal interpretation of the statement from Qur'an "in tubtum fa wa lakum ru'usu amwalikum". The term "ru'usu amwalikum" is defined as a loan. Therefore, they argue that any extra over and above the loan can be categorized as riba.4 5

The second group is modernists. The group stressed the importance of refresher Islamic thought by way of reviving ijtihad that used as a tool to obtain the relevant ideas of al-Quran and as-Sunnah and trying to formulate legal needs. In more detail, Saeed Iqbal in identifying existing 5 modernist traits, 46 namely (1) selective in using the Sunnah; (2) develop a pattern of systematic thinking by eliminating the assumption that decides about the end of the thinking activity; (3) makes a distinction between shariah and fiqh; (4) avoiding understand that accentuated sectarian, and (5) change the characteristics of thinking method.

Based on the above characteristics, among modernists such as Fazlur Rahman, Muhammad Asad, an-Najjar Said and Abd al-Moneim an-Namir more emphasis on the moral aspect in understanding the prohibition of riba and override the formal legal riba itself. Rational understanding of the riba prohibition lies in the injustice as the reason to forbid riba base on Qur'an that

${ }^{41}$ Ibid, p. 8.

42 Ibid, p. 849.

${ }^{43}$ M. Umar Capra, Towards a Just Monetary System, (London: Islamic Fondation, 1995), p. 57.

${ }^{44}$ Muslim Muslihun, op.cit., p. 147.

${ }^{45}$ Saeed Abdullah, op.cit., p. 119.

${ }^{46}$ Ibid, p. 7. 
said "La tadzlimun wa la tudzlamun", therefore riba is distinguished by bank interest. The group is also based its opinion on the classical Muslim scholars, such as al-Razi, Ibn al-Qayyim and Ibn Taymiyyah that the riba prohibition related to the moral aspect refers to the practice of riba in pre-Islamic. 4

Based on the explanation above, apparently riba is prohibited because it contains an element of exploitation to the poor, not the interest factor. This exploitation is done through loans that are trying to take advantage from the loan that resulting misery of others. Some modernist views on bank interest was permissible according to Muslims due to some factors: ${ }^{48}$

1. The existence of need and dharurah(emergency) in economic life, as Sanhuri's opinion

2. There is a difference between consuming loan with productive loan, productive loan is allowed but consuming loan is not permissible, as Doulibi said.

3. There is a difference between riba (usury) and interest. In this view riba is forbidden, not bank interest, as well as the view of Hafni Nasif and Abdul Aziz Jawish.

4. The existence of inflationary economic in the economic mechanism, so that the rising of interest rates will correct the creditors disadvantage caused by inflation, as Syauqi Dunya said.

From above description, apparently the debate around bank interest related to the riba problem will not be end. Two opinions were conflicting between modernist and neo-revivalism is impossible to meet each other because each group looked from different perspective and approach.

The group that tend to align interest with riba in approaching the problem of formal legal side or Minhaji " 49doctrinaire - deductive - normative " . According to him, to answer the various issues that arose, usul fiqh as a science which is competent in this fiel recognizes two approaches, namely doctrinaire - normative- deductive and empirical - historical - inductive. In some certain laws, to understand Qur'an, Sunnah and relations between them, ijma, ijtihad and the processes surrounding it required a combination of both models of these approaches simultaneously.

This can be seen from their discussion who just put nash, text and less put attention to the objective aspects of the existence of banks as a collector and distributor of funds (financial intermediary) that have great impact on the economic and social.

${ }^{47}$ Ibid, p. 41.

${ }^{48}$ Muslim Muslihun, op.cit., p. 148.

49 Akhmad Minhaji, Reorientasi Kajian Ushul Fiqh “dalam Al-Jami'ah Journal of Islamic Studies, IAIN Sunan Kalijaga Yogyakarta, No.63/VI/1999, p. 16-17 
On the other hand, a group that supports the lawfulness of bank interest, approach this issue more emphasis on the objective existence of banks, or Minhaji's term " empirical -historical - inductive ". Yet this group did not ignore at all aspects of the text, they placed nash in an ideal-moral position that keep put their own product of law in their heart (Rahmi, 2001: 150).$^{50}$

\section{The concept of Riba in Islamic Finance Rationality}

The controversy among Muslim scholars' opinion toward riba and interest rates showed that the problem of riba is very closely related to the issue of money. The evolution of the concept of riba to interest cannot be separated from the development of financial institutions. Financial institutions were arising from capital requirements to finance industry and commerce. That is why, it should be examined in depth the issue of riba associated with Islamic financial problems.

\section{The concept of Money in Islam}

Money is known as something that is generally accepted by the public as legal tender, well used to pay for purchases of goods and services or used to pay off debts. In other words, money is an integral part of human life because money is a means of facilitating the movement of goods and services in all economic activities.

Generally, the money based on the function or purpose use can be defined as an object which can be exchanged with other objects; can be used to measure other objects; as a store of wealth and to pay the debt in the future. ${ }^{51}$ Meanwhile, Samuelson in Ascarya define money as a medium of exchange modern and standard units to set prices and debt. In line with the above definition, Abbott Lawrence interpret money is anything generally accepted by certain economic areas as a means of payment for the purchase or debt.52

Meanwhile, some conventional economic literature defines money from the roles and functions of money itself in the economy, namely money as ( 1 ) a medium of exchange ; (2) a store of value ; (3)The unit of account / measure of value ; and ( 4 ) the standard for deferred payment.53 While the motive of holding money, according to Keynes in Karim , there are three motives : (1) transaction motive; (2) The precautionary motive; and (3) speculative motive. The third motive of this, the interest rate as the cost of opportunity appears,

\footnotetext{
${ }^{50}$ Rahmi Nispan, Konsep Ibnu Qayyim al-Jauziyah Tentang Riba" dalam Tesis Magister IAIN Sunan Kalijaga Yogyakarta, 2001, p. 150.

${ }^{51}$ Rivai Veithzal dkk, op.cit., p. 3.

${ }^{52}$ Ascarya, op.cit., p. 22

${ }^{53}$ Rivai Veithzal dkk, op.cit., p. 3-4.
} 
where the higher the interest rate, the lower the speculative demand for money, and vice versa. 54

The concept of money is somewhat different from the concept of money in Islamic economics as a new paradigm in the world economy. In Islamic economics, the concept of money is very clear and firm that money is money, money is not capital. In contrast, the concept of money raised in conventional economics is often interpreted as interchangeability namely money as money and money as capital.55

According to Ibn Taymiyya in Islahi, money in Islam is a means of exchange and a measure of value. The money is intended as a measure an item, through money, the value of the goods will be known and they do not use it for theirself or consumed. Similar thing also expressed by his student, Ibn Qayyim that money and coins does not intended for the object itself, but for the purpose of obtaining goods ( as a medium of exchange ) .56 In relation to the concept of money, al- Ghazali in Muhammad revealed that: "money is like glass, has no color, but it can reflect all colors. Money does not have a price, but the money can reflect on all the prices".57

From the definitions and theories about money above, generally money in Islam is defined as a medium of exchange and measure of value of goods and services to facilitate economic transactions. Thus, money is not a commodity. Therefore, the motive of holding money in Islam is for the transaction and precaution only, and not for speculation. 58

Another difference regarding the concept of money between Islamic economics and conventional economics is money is something that is flow concept and the capital is something that is a stock concept. Whereas in conventional economics there are two (2) views on the concept of money as follows :

First, the concept of Irving Fisher, as stated by Frederic S. Mishkin in Karim that the faster the velocity of money, the greater the income earned. This could mean that money is a flow concept. In other words, there is absolutely no correlation between the necessity of holding money (demand for holding money) with interest rates. ${ }^{59}$

This concept can be expressed in the following equation :

${ }^{54}$ Adiwarman Karim, Ekonomi Makro Islam, (Jakarta: Raja Grafindo Persada, 2007), p. 182-183.

${ }^{55}$ Ibid, p. 77.

${ }^{56}$ Islahi Abdul Azim, p. 140

${ }^{57}$ Muhammad, Dasar-dasar Keuangan Islam, (Yogyakarta: UPP AMP YKPN, 2005), p. 46.

${ }^{58}$ Ascarya, op.cit., p. 22-23. 2007), p. 77.

59 Adiwarman Karim, Ekonomi Makro Islam, (Jakarta: Raja Grafindo Persada, 
Description:

$\mathrm{M}=$ Amount of money $\mathrm{k}=1 / \mathrm{v}$

$\mathrm{P}=$ price level of goods

$\mathrm{T}=$ Number of traded goods

Second, the concept of Pigou Marshall of Cambridge in Karim (2007: 78 ) as was stated by Mishkin, which was expressed in the following equation $:^{60}$

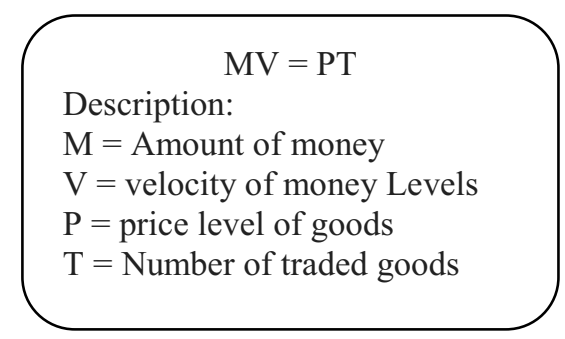

Marshall mathematical equation above shows that demand for holding money is a proportion $(\mathrm{k})$ of the total revenue (PT). The larger the $\mathrm{k}$, the greater the demand for holding money (M) to a certain income level (PT). It shows that the concept of Marshall stated that money is a stock concept. Therefore, the Cambridge group says that money is one way to store wealth. In Islam, capital is private goods, while the money is public goods. When the money flows are public goods (flow concept) and then settles into a person's ownership (stock concept) and the money is being privately owned (private goods). The description of the money concept as a flow concept and public goods can be explained as follows:

\section{Money as a Flow Concept}

In Islam, money is a flow concept, while capital is a stock concept (Muhammad, 2004: 71). The faster the velocity of money, the better. Money can be likened to water. If the water flowed, then the water will be clean and healthy. But if the water is allowed to stagnate in one place, then the water will be muddy (gross). Likewise money, it rotates to production can lead to economic prosperity and public health. Meanwhile, if the money was detained, it can cause a breakdown of the economy so as to cause the economic crisis. So, the money should be used for investment in the real sector. If only saved money, then not only do not get a return, but also is subjected to zakat.

\footnotetext{
${ }^{60} \mathrm{Ibid}$, p. 78
} 


\section{Money as Public Goods}

Money as public goods is characterized as items that can be used by people without blocking other people to use it. ${ }^{61}$ Money as public goods likened highways and capital as private goods likened as vehicle. The highway can be used by anyone without exception, but the people who have a vehicle has larger opportunity in using the highway compared to people who do not have vehicles. So does with money. Money as public goods can be used more by the community richer. It is not because their deposits in the bank, but because of their assets, such as houses, cars, stocks, and others that are used in the production sector, thus providing a greater opportunity for the person to obtain more money. Thus, the higher the production level, the greater the opportunity to take advantage from the money (public goods). Therefore, stockpiling is prohibited because deter others from using such public goods.

Table 3. The concept of money according to the Economic Conventional and Islamic Economics

\begin{tabular}{|c|c|c|}
\hline Money & Conventional Economic & Islam Economic \\
\hline $\begin{array}{l}\text { Money } \\
\text { Concept }\end{array}$ & $\begin{array}{l}\text { 1. Money is identical to } \\
\text { the capital } \\
\text { 2. Money ( capital ) are } \\
\text { private goods } \\
\text { 3. Money ( capital ) is a } \\
\text { flow concept for Fisher } \\
\text { 4. Money ( capital ) is the } \\
\text { stock of Concept for } \\
\text { Cambridge School }\end{array}$ & $\begin{array}{l}\text { 1. Money is not identical } \\
\text { to the capital } \\
\text { 2. Money is public goods } \\
\text { 3. Capital is the private } \\
\text { goods } \\
\text { 4. Money is a flow concept } \\
\text { 5. Capital is a stock } \\
\text { concept }\end{array}$ \\
\hline $\begin{array}{l}\text { Money } \\
\text { function }\end{array}$ & $\begin{array}{l}\text { 1. Medium of Exchange } \\
\text { 2. Store of Value } \\
\text { 3. Unit } \\
\text { Account/Measure of } \\
\text { Value } \\
\text { 4. Standard for Deferred } \\
\text { Pavment }\end{array}$ & $\begin{array}{l}\text { 1. Medium of Exchange } \\
\text { 2. Unit of } \\
\text { Account/Measure of } \\
\text { Value }\end{array}$ \\
\hline
\end{tabular}

The differences and similarities actually can be concluded from the theory of each of the demand for money. From the difference in this concept, the idea appears about economic interest in the outcome of conventional and Islamic economics which was applied in the banking concept.

\footnotetext{
${ }^{61}$ Adiwarman Karim, op.cit., p. 87.
} 


\section{Money in the Islamic Economic System}

In the history of Islamic economy, the importance of money is confirmed by the opinion of the Prophet Muhammad who advocate that the better trading ( fair ) is the trade that uses the medium of money ( dinar or dirham ), rather than the exchange of goods (barter) which can lead to riba when the exchange of goods a different kind of quality.

By the existence of money, the economy (in the perspective of Islam) can take place with a better, that is maintained and increased turnover velocity between the human (economic actors). Due to the presence of money, charity activities, infaq, sadaqah, endowments, kharaj, jizya, and others can be smoothly held. With the existence of money as well, the activity of the private sector, public , and social can take place at a faster acceleration .

The difference concept of money between conventional economics and Islamic economics has implications for the economy. In conventional economics, the system of interest and functions of money which can be likened to a commodity causes its own market with money as a commodity and interest as the price. This market is growing monetary market parallel to the real market ( goods and services ) in the form of money market, capital market, bond market and derivatives market. As a result, in the conventional economy arising dichotomy real and monetary sectors. Furthermore, the rapid development in the monetary sector has been siphoning money and productivity or value added generated real sector so that the monetary sector has inhibited the growth of the real sector, has even narrowed the real sector, causing inflation and hamper economic growth. 62

This inflation will further made reference to raise interest rates. When the level of profit expected by investors and entrepreneurs is lower than the prevailing interest rates, then certainly the entrepreneurs and investors will be reluctant to invest. Theoretically, in the conventional financial system, someone will invest to the level of marginal efficiency of capital (marginal efficiency of capital) equal to the rate of return on interest payments due to investment behavior depends on the interest rate and the rate of profit expectations. The higher the interest rate, the lower the level of investment will be. This will certainly exacerbate the unemployment problem if capital owners are reluctant to invest because of the profits they make less than the prevailing interest rates. Termination of this investment will indirectly result in not exploited the economic resources and reduce employment opportunities for people who need a job or even occur layoffs. 63

${ }^{62}$ Ascara, op.cit., p. 25-26.

${ }^{63}$ A. Mansur, Konsep Uang dan Bank: Studi Komparasi Antara Ekonomi Konvensional dan Ekonomi Islam, dalam Ontologi Kajian Islam, Seri 9, 2005, p. 206207. 
The dichotomy of the real sector and monetary economics does not occur in Islam because of the absence of interest and banning trade system as commodity money so that patterns of Islamic economy is the real economy with the function of money as a medium of exchange to facilitate the activities of investment, production and trade in the real sector.

\section{Prohibition of Riba in Islamic Financial System}

The prohibition of usury, according to Qaradawi has benefit lesson hidden behind the prohibition, that is the embodiment of a fair equation between property owners (capital) to businesses, as well as the risks and consequences take full of a sense and responsibility. The principle of justice in Islam is not partial to one side, but both are in a balanced position.

The concept of prohibition of riba in Islam can be explained with its economic advantages contain in it compared with conventional economic concept . Riba is economically more an attempt to optimize the flow of investment by maximizing the possibility of prohibiting their investment through ascertainment (interest). The higher the interest rate, the more likely the unstoppable flow of investment is. It can be likened to such a dam. The higher the dam wall, the greater the flow of water is stoppable. ${ }^{64}$

With the prohibition of riba, the wall that separate the flow of investments is nothing so the flow run smoothly without a hitch. This is could be seen when Indonesia was hit by the financial and banking crisis in 19971998. At that time, banks' interest rates soared high to reach $60 \%$. With the interest rates as high as it can be said almost no one who dared to borrow for investment bank. This can be illustrated in Figure 1

Figure 1 Flow Investment unstoppable

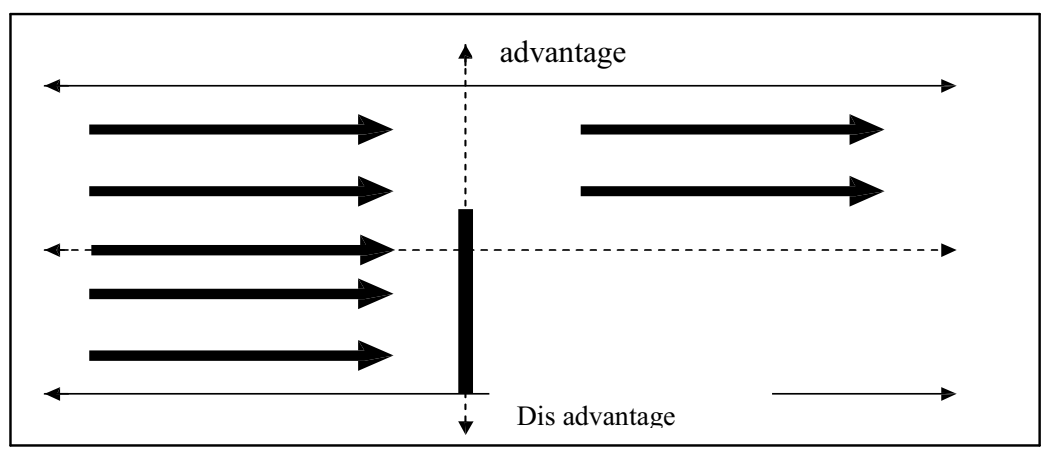

Source : Ascarya, 2007: 18 .

${ }^{64}$ Ascaryah, op.cit., p. 17. 
Graphically, it can be shown that the increased rate of $\mathrm{y} \%$ to $\mathrm{x} \%$ has reduced the number of possible investment from Q1 into Q2 (see chart 1). The increase in interest rates has been to stem the flow of investment of Q1 - Q2. Because of this, the riba is forbidden in Islam (besides reasons of morality) . Graph 1. Interest Rate and Investment Relations

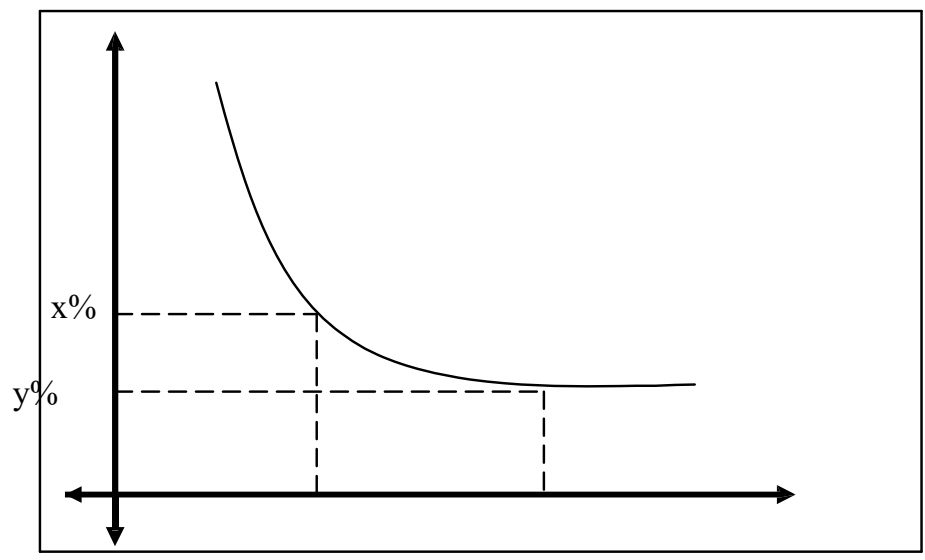

Source : Ascarya , 2007: 19 .

From the explanation above, the implications of the prohibition of riba in the real sector, according Ascarya, as follows: ${ }^{65}$

1. To optimize investment flows smoothly channeled to the real sector.

2. To prevent the accumulation of wealth to a group of people, when it has the potential to exploit the economy (the exploitation of economic actors on other actors; exploitation of the system on economic operators);

3. To prevents interferences in the real sector, such as inflation and the decline in macro-economic productivity;

4. To encourage the creation of economic activity fair, stable and sustainable through a mechanism for the results (profit-loss sharing) productive.

Thus, due to the prohibition of riba in Islam make the flow of investment to be optimal and channeled to productive sectors. Meanwhile, in the conventional system interest system makes optimal investment flows into and not smooth due partly obstructed. Whereas in the absence of gambling prohibition, some investments are not channeled to productive sectors as shown in Figure 2

Figure 2. The flow of investments in the Islamic and Conventional System

$$
{ }^{65} \text { Ibid, p. } 19 .
$$




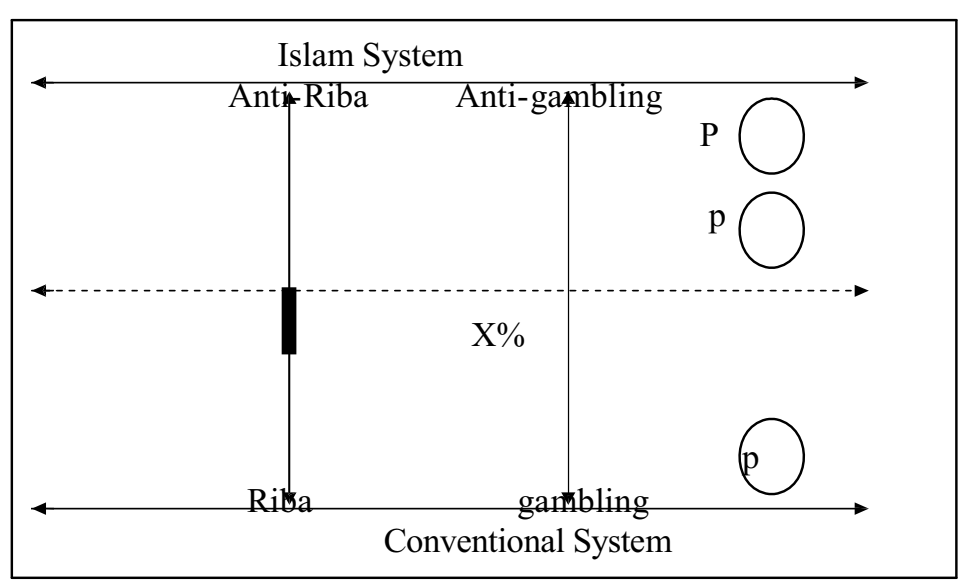

Source: Ascarya, 2007: 21.

Furthermore, when riba only includes usury, the focus of Islamic economic development will just lead to improvements and completeness of Islamic economic regulation of infrastructure, which include Islamic financial institutions (banks sharia, shariah insurance, capital markets shari'ah, and so on). However, when riba including interest, then focus on the development of Islamic economics also lead to macroeconomic structure and gold-based monetary management (full bodied money) in the long-term dimension. ${ }^{66}$

\section{The Ways of Money Development without Containing Riba}

Riba is a form of economic transactions where the unlawfulness did not caused by its substance, however due to transactions performed ( haram lighairihi ). Therefore, actually, riba can be removed in some ways that described in Table 4 as follows:

Table 4. How to Eliminate Causes Riba

\begin{tabular}{|c|l|l|}
\hline \multicolumn{1}{|c|}{ RIBA TYPE } & \multicolumn{1}{|c|}{$\begin{array}{c}\text { THE CAUSE } \\
\text { FACTOR }\end{array}$} & $\begin{array}{l}\text { HOW TO ELIMINATE THE } \\
\text { CAUSE FACTOR }\end{array}$ \\
\hline Riba al-Fadl & $\begin{array}{l}\text { Gharar (uncertain to } \\
\text { both parties) }\end{array}$ & $\begin{array}{l}\text { Both parties must ensure } \\
\text { the following factors : 1 ) the } \\
\text { quantity ; 2) quality ; 3 ) price ; } \\
4 \text { ) time of delivery }\end{array}$ \\
\hline
\end{tabular}

${ }^{66}$ Ibid, h. 21. 


\begin{tabular}{|c|l|l|}
\hline Riba Nasi'ah & $\begin{array}{l}\text { Return without risk, } \\
\text { revenue without charge }\end{array}$ & $\begin{array}{l}\text { Both sides made a contract } \\
\text { which details the rights and } \\
\text { obligations of each to ensure the } \\
\text { absence of any party who earn a } \\
\text { return without risk or enjoy } \\
\text { revenue without the costs }\end{array}$ \\
\hline $\begin{array}{c}\text { Riba } \\
\text { Jahiliyah }\end{array}$ & $\begin{array}{l}\text { Voluntary commercial } \\
\text { lending because every loan } \\
\text { that take a profit from it is } \\
\text { riba }\end{array}$ & $\begin{array}{l}\text { Do not take any benefit from } \\
\text { goodness contract ( tabarru ) If } \\
\text { they want to take profit from the } \\
\text { use of business agreement ( } \\
\text { tijarah ) not contract goodness } \\
\text { tabarru' })\end{array}$ \\
\hline
\end{tabular}

Source: Karim, 2007: 42.

The teachings of Islam prohibits riba and encouraged the people to invest because there is a fundamental difference between the investment and riba. According to Antonio, the differences can be analyzed from the definition to each of meaning, namely: ${ }^{67}$

1. Investing is risky business activities for dealing with the element of uncertainty. Thus, the acquisition of his return is uncertain and not fixed.

2. To lend the money is less risky business because of its acquisition of the return of interest is relatively definite and fixed.

This investment can be done through economic cooperation is carried out in all lines of economic activity, either production or consumption and distribution. One form of cooperation in the business of Islamic economics is Musharaka or Mudaraba. Through this transaction, both parties to the partnership will not get interest, but profit and loss sharing of economic cooperation as mutually agreed. Profit-loss sharing can be regarded as a system of cooperation that emphasizes fairness in the Islamic business, so it can be used as an alternative solution instead of the system of interest.

\section{E. Profit and Loss Sharing as rational solution toward Interest}

As an alternative to the system of interest in conventional economics, Islamic economic system offers profit and loss sharing, when the owners of capital (surplus spending unit) in collaboration with employers (deficit spending units) to conduct business activities. When generating business resulted the profits, it is shared and if the business activities suffered a loss, the loss is also equally shared. The system of this profit sharing can be in Musharaka or mudaraba with different variations.

\footnotetext{
${ }^{67}$ Muhammad Syafi'i Antonio, op.cit., p. 59.
} 
In mudaraba, there are business cooperation between two parties where party of shahibul mall provides the entire capital, while the other party as mudharib (manager). Mudaraba business profits are divided according to the agreement set forth in the contract, whereas loss is borne by the owners of capital losses as long as that is not due to mudharib's negligence. However, if the loss was caused by mudharib's negligence, he should also be responsible for the losses. ${ }^{68}$

Another alternative as the change of interest is equity participation through the expected rate of return is called Musharaka. The real sector is the most important sector highlighted by Islamic economy because it is directly related to the increase of output and finally the welfare of society. All components in the economy geared to encourage the real sector, both in motivating businesses and in terms of financing. ${ }^{69}$

Expectations return, different with the interest rate that always justified by time value of money, but it is associated with the economic value of money. Thus, the factors that determine the value of time is how someone used the time. The more effective and efficient, the higher the value of time is. By using time effectively to work and strive will generate revenue that can be valued by money. This contrasts with the time value of money, which is not in proportion to consider the probability of deflation, in addition to inflation. Because in reality, the uncertainty is always occurred, and become unfair if only demand for certainty, as what occur in conventional economics through the concept of time value of money. Therefore, investor in Islam has no right to ask for a rate of return where the value is remained and no one has right to receive additional principal embedded capital without participation to take a risk. 70

Thus, the system of profit and loss sharing, both mudharabah and musyarakah will be able to ensure justice and the absence of the exploited. Through a revenue sharing system will also awaken equity and solidarity as well as creating a more equitable economic order.71

Whereas in the conventional economy, riba system, fiat money, commodity money, and the permissibility of speculation will lead to the creation of money (currency and demand deposits) and the inhalation of money in the monetary sector for gaining profit without risk. As a result, money or investments that should be channeled to the real sector for productive purposes largely fled to inhibit the growth of the monetary sector and the real sector even

\footnotetext{
${ }^{68}$ Ibid, p. 95.

${ }^{69}$ Masyhuri dkk, Teori Ekonomi dalam Islam, (Yogyakarta: Kreasi Wacana,

${ }^{70} \mathrm{Ibid}, \mathrm{p} .109-110$.

${ }^{71}$ Ascarya, op.cit., p. 26.
} 2005), p. 108-109. 
shrinks. Furthermore, the creation of money without any value added will lead to inflation. Finally, the objectives of economic growth will be hampered.

\section{Figure 3. Interest on Economic Implications}

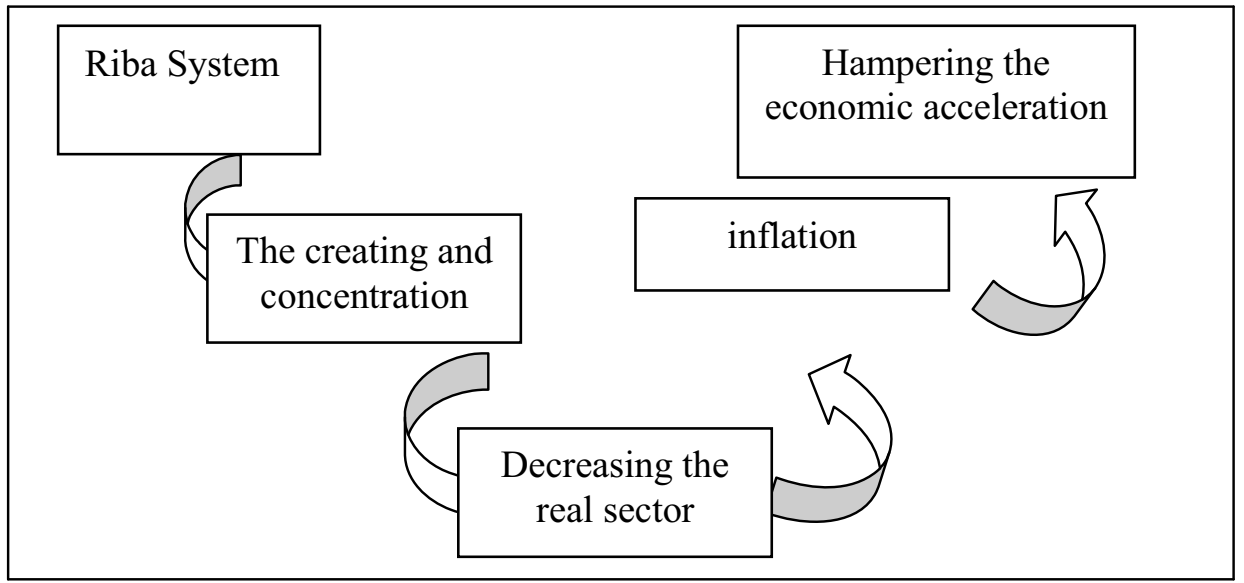

Thus, Islam encourages the practice of profit and loss sharing and forbidden riba. Although both can provide benefits to the owners of capital, but both have a very fundamental difference.

That difference can be explained in Table 5 below.

\section{Table 5. The difference between interest and Sharing}

\begin{tabular}{|c|c|}
\hline Interest & Profit And Loss Sharing \\
\hline $\begin{array}{l}\text { 1. Determination of interest at the time the } \\
\text { contract was made with the assumption } \\
\text { that the business will always make a } \\
\text { profit. } \\
\text { 2. The percentage is based on the amount } \\
\text { of funds / capital lent. } \\
\text { 3. Interest can be floating / variable, and } \\
\text { the magnitude of up and down } \\
\text { according to the rise and fall of the } \\
\text { benchmark interest or economic } \\
\text { conditions. } \\
\text { 4. Payment of interest remains as promised } \\
\text { without consideration of whether the } \\
\text { borrower's business carried on profit or } \\
\text { loss. } \\
\text { 5. Total interest payments are not } \\
\text { increased despite rising profits doubled. } \\
\text { 6. Existence doubtful interest (if not } \\
\text { condemned) by all religions. }\end{array}$ & $\begin{array}{l}\text { 1. Determination of the ratio } \\
\text { revenue sharing was agreed at the } \\
\text { time of the contract based on the } \\
\text { likelihood of profit and loss. } \\
\text { 2. The amount of profit sharing ratio } \\
\text { based on the amount of profits. } \\
\text { 3. The ratio for the results remained } \\
\text { unchanged for the contract is still } \\
\text { valid, unless amended by mutual } \\
\text { consent. } \\
\text { 4. For results depend on business } \\
\text { profits run. When businesses lose } \\
\text { money, the loss will be shared. } \\
\text { 5. The amount of profit sharing } \\
\text { increased according to the increase } \\
\text { in profits. } \\
\text { 6. There is no doubting the validity of } \\
\text { the results. }\end{array}$ \\
\hline
\end{tabular}


Source: Antonio, 2001: 61.

Meanwhile, the profit-sharing system and the prohibition of riba in Islamic economy will encourage the investment climate be channeled smoothly into the real sector for the purpose of fully productive. This will ensure the distribution of wealth and income and foster real sector. By increasing productivity and employment opportunities and to strive for economic growth eventually will be pushed and achieved the welfare of society (see Figure 4).

\section{Figure 4. Implications for the Economy Results}

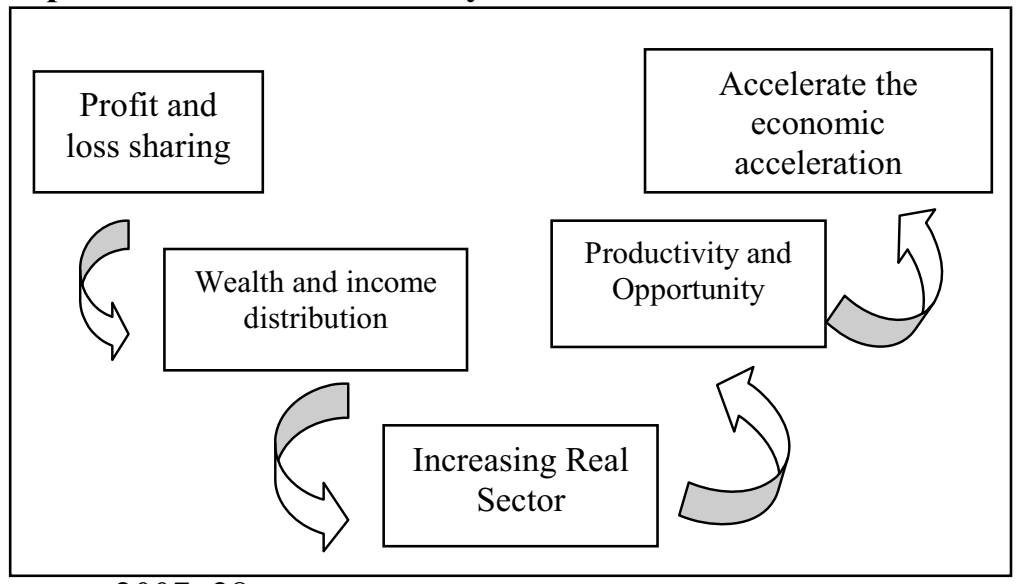

Source: Ascarya, 2007: 28.

Description and illustration above shows that the model of profit and loss sharing is a model of Islamic finance non-riba (not interest-based), which can be an alternative solution to the banking system. This model may have implications for the creation of a just economic activity, towards achieving stable and sustainable public welfare.

\section{F. Conclusion}

Pure Interest theory and the monetary theory are the concepts that basically do not have a strong foundation in sustaining the resilience of a country's economy, and in the concept of Islamic economics, interest is part of the implementation of Riba,. Therefore, prohibition of riba as one of the main pillars of Islamic economics that aims to create a system that supports the investment climate must be applied. The implications of riba prohibition in the real sector, which can encourage the optimization of investments, preventing the buildup of assets at a group of people, prevent inflation and a decrease in productivity and encourage the creation of economic activity fair.

The presence of Islamic economics in the middle of the community is to create economic justice and income distribution towards the achievement of social welfare. Islam puts economic justice for all businesses, not familiar with 
the term "creditor" and "debtor", but partners who are equally bear the risk with a full sense of responsibility. Finally, profit and loss sharing system can be used as an alternative solution the system of interest in Islam is a rational economic system.

\section{REFERENCE}

Abadi, Al-Fairuz, 1998. Al-Qamus al-Muhit, Beirut: Dar al-Fikr.

Antonio dan Muhammad Syafi'i. 2001. Bank Syari'ah: Dari Teori ke Praktik, Jakarta: Gema Insani Press.

Arifin, Zainul, 1999. Memahami Bank Syari'ah, Jakarta: Alvabet.

Ascarya, 2007. Akad dan Produk Bank Syariah, Jakarta: RajaGrafindo Persada.

Chapra dan M. Umer, 1995. Towards a Just Monetary System, London: Islamic Foundation.

Djamil, Fathurrahman . 1995. Metode Ijtihad Majelis Tarjih Muhammadiyah, Jakarta: Logos Publishing House.

Iqbal, Zamir dan Abbas Mirakhor, 2007. An Introduction to Islamic Finance, Wiley: John Wiley and Sons (Asia) Pte Ltd.

Islahi, Abdul Azim. 1988 . Economic Concepts of Ibn Taimiyah, London: The Islamic Foundation.

Jaziri, Abdurrahman, 1972. Kitab al-Fiqh 'ala Mazahib al-Arba'ah, Beirut: Dar al- Fikr.

Karim, Adiwarman, 2007. Bank Islam: Analisis Fiqh dan Keuangan, Jakarta: RajaGrafindo Persada.

Karim, Adiwarman, 2001 . Ekonomi Islam, Suatu Kajian Kontemporer, Jakarta: Gema Insani Pres.

Karim, Adiwarman, 2007. Ekonomi Makro Islami, Jakarta: RajaGrafindo Persada.

Mannan, Muhammad Abdul, 1997. Islamic Economic, Theory and Practice, terj. Nastangin, Yogyakarta: Dana Bhakti Wakaf.

Mansur, A., "Konsep Uang dan Bank: Studi Komparatif antara Ekonomi Konvensional dan Ekonomi Islam", dalam Ontologi Kajian Islam, seri 9, Juli 2005.

Masyhuri dkk., 2005, Teori Ekonomi dalam Islam, Yogyakarta: Kreasi Wacana.

Minhaji, Akhmad. "Reorientasi Kajian Ushul Fiqh" dalam al-Jami'ah 
Journal of Islamic Studies, IAIN Sunan Kalijaga Yogyakarta, No. 63/VI/1999.

Mubyarto, 2007. Membangun Sistem Ekonomi, Yogyakarta: BPFE.

Muhamad, 2001. Teknik Perhitungan Bagi Hasil dan Profit Margin pada bank Syari'ah, Yogyakarta: UUI Press.

Muhamad, 2005. Dasar-Dasar Keuangan Islam, Yogyakarta.

Muhamad, 2005. Manajemen Bank Syari'ah, Yogyakarta: UPP AMP YKPN.

Muslim, Muslihun, 2005. Fiqh Ekonomi, Mataram: LKIM.

Nasution, Mustafa Edwin dkk, 2006. Pengenalan Eksklusif Ekonomi Islam, Jakarta: Kencana.

Rahman, Afzalur. 2002. Economics Doctrines of Islam, terj. Soeroyo dan Nastangin, Jakarta: Dana Bhakti Wakaf.

Rahmi, Nispan, 1374 H."Konsep Ibnu Qayyim al-Jawziyah Tentang Riba", dalam Tesis Magister Agama, IAIN Sunan Kalijaga Yogyakarta, 2001. Ridha, Al-Manar, Mesir: Mathba'ah M. Ali Shihab wa Abduh.

Rivai, Veithzal , 2007. dkk, Bank and Financial Institution Manajement Conventional and Sharia System, Jakarta: RajaGrafindo Persada, 2007.

Saeed, Abdullah, Islamic Banking and Interest, A Study of Prohibition of Riba and its Contemporary Interpretation, Leiden: E.J. Brill.

Suharto, Ugi , "Paradigma Ekonomi Konvensional dalam Sosialisasi Ekonomi Islam", dalam ISEFID Review, Vol.3, No.3, 2004.

Tim Pengembangan Perbankan Syari'ah Institut Bankir Indonesia, 2001. Bank Syari'ah: Konsep, Produk dan Implementasi Operasional, Jakarta: Djambatan.

At-Tirmidzi, Abu Isa Muhammad bin Isa bin Saurah, 1964. Sunan atTirmidzi wa Huwa al-Jami' as-Shahih, Beirut: Dar al-Fikr.

Vogel, Frank E. dan Samuel L. Hayes, 2007. Islamic Law and Finance: Religion, Risk, and Return, terj. M. Sobirin, dkk, Bandung: Nusamedia.

Wirdyaningsih et.al, 2005 , Bank dan Asuransi Islam di Indonesia, Jakarta: Kencana.

Al-Zuhaili, Wahbah, 1989. Al-Fiqh al-Islami wa Adillatuh, Beirut: Dar alFikr. 